\title{
Twenty-one years without monetary correction in Brazil: impacts on the comparability of the accounting information of siderurgical and metallurgical companies ${ }^{\star}$
}

\author{
Wellington Rodrigues Silva Souza ${ }^{1}$ \\ (D) https://orcid.org/0000-0003-0350-1639 \\ Email: profwrodrigues@gmail.com \\ Marcos Peters ${ }^{1}$ \\ Email: marcospeters@marpet.com.br \\ Aldy Fernandes da Silva ${ }^{1}$ \\ (iD) https://orcid.org/0000-0003-3686-9288 \\ Email: aldy@fecap.br \\ Maria Thereza Pompa Antunes ${ }^{2}$ \\ (D) https://orcid.org/0000-0002-9501-2789 \\ Email: maria.antunes@fipecafi.org \\ ${ }^{1}$ Fundação Escola de Comércio Álvares Penteado, Mestrado Acadêmico em Ciências Contábeis, São Paulo, SP, Brazil \\ ${ }^{2}$ Faculdade Fipecafi, Mestrado Profissional em Controladoria e Finanças, São Paulo, SP, Brazil
}

Received on 06.05.2017 - Desk acceptance on 06.26.2017 - $5^{\text {th }}$ version approved on 12.28.2017 - Ahead of print on 07.26.2018 Associate Editor: Eliseu Martins

\section{ABSTRACT}

The purpose of this study was to empirically verify the existence or not of a distortion in the comparability of information when inflationary effects are omitted from financial statements. Although inflation has been under control in Brazil since the Plano Real, with indices well below those recorded in the 1980s and 1990s, discussing the need for accounting recognition of the effects of inflation remains an extremely relevant and pertinent issue in light of the proposal of accounting to produce faithful information that closely reflects the economic reality in which organizations operate. The results of the research show that financial accounting has been directly affected by the omission of inflationary effects in financial statements, drawing attention to the negative effects this has caused on the quality of the information produced. In order to operationalize the research, the Balance Sheet Monetary Correction (BSMC) was applied to the balance sheets of Brazilian companies from the siderurgical and metallurgical sector listed on the BM\&FBOVESPA in the period from 1996 to 2016. Based on the variables net income, return on equity (ROE), and return on assets (ROA), and two conceptual axes of comparability (between entities and between periods), the statistical parameters were developed and the hypotheses were defined, which were tested using the Student t parametric test. This article shows the damage caused to the decision-making process of the external users for whom financial statements are intended when these are prepared neglecting the effects of inflation. This is verifiable through the analyses of the results obtained, including the observation of significant distortions between the means of the corrected indicators and the means of the historical indicators, such as in the case of net income in 2001, 2002, 2012, 2013, 2014, and 2016 (33.98\%, 91.92\%, $-65.54 \%,-30.01 \%,-53.59 \%$, and $26.30 \%$ variation, respectively), of ROE $(-67.16 \%,-61.43 \%,-53.06 \%$, $-63.46 \%,-133.81 \%$, and $65.00 \%$ variations in $2008,2009,2010,2011,2014$, and 2015 , respectively), and of ROA $(-26,70 \%$, $-41.14 \%,-33,34 \%,-43,49 \%, 98,83 \%$, and $-413,68 \%$ in $2005,2009,2010,2011,2012$, and 2014, respectively).

Keywords: monetary correction, inflation, quality of information, comparability, investor.

\section{Correspondence address}

Wellington Rodrigues Silva Souza

Fundação Escola de Comércio Álvares Penteado, Mestrado Acadêmico em Ciências Contábeis

Avenida Liberdade, 532 - CEP: 01502-001

Liberdade - São Paulo - SP - Brazil

* Article presented at the XL ANPAD Meeting, Costa do Sauípe, BA, Brazil, September 2016. 


\section{INTRODUCTION}

Obligatory monetary correction in financial statements in Brazil dates back to 1964, when Act n. 4,357 (1964) determined the correction of property, plant, and equipment. Some years later, via Act n. 6,404 (1976), balance sheet monetary correction (BSMC) was institutionalized, foreseeing adjustments in permanent assets and net equity to reflect the effects of inflation. Due to the constant rise in price levels, in 1987 the Brazilian Securities and Exchange Commission (CVM) issued CVM Instruction n. 64 (1987), determining the full monetary correction of accounting statements in addition to the statements elaborated based on corporate law.

After various failed attempts to contain inflation in the country, which in 1993 reached 2,477.15\% based on the Extended Consumer Price Index - IPCA (Brazilian Institute of Geography and Statistics - IBGE, 2017b), the Plano Real prevailed, achieving monthly reductions in the local rate of inflation. Simultaneously to the benefits of the plan, Act n. 9,249 (1995) prohibited the recognition of the effects of inflation in accounting, both for tax and corporate purposes.

Various authors, including Feitosa (2002), Melo, Martins, Nagai, Amaral, and Salotti (2012), Porto (1998), and Salotti, Lima, Corrar, Yamamoto, and Malacrida (2006), have sought to demonstrate that the impacts of the absence of monetary correction have persisted over time, prevailing over the 1990s and 2000s and still remaining a relevant problem in the Brazilian economic setting in 2010. For these authors, this has contributed to the persistence of a distortion of results, a compromised informative ability, and a loss in the transparency of accounting statements.

The evolution of accounting over time has been accompanied by concerns about improving informational quality. In the Brazilian context, the Accounting Pronouncements Committee (CPC) issued Basic Conceptual Pronouncement - R1 (2011), which discusses the qualitative characteristics of information, including comparability, both between different companies and between periods for the same company.
In various studies, such as those of Franco, Kothari, and Verdi (2011), Kang (2012), Reina, Reina, and Silva (2014), and Yip and Young (2012), the argument is verified that the convergence of the local accounting standards with the international standards enables the production of information that is comparable between different countries. There is, however, a previous point to this fact that should be discussed: since the effects of inflation on accounting statements were not recorded, it is to be supposed that these are being compared on different monetary bases, which may cause informational damage to their users.

In this context, this study aims to answer the following research question: what is the evidence of the impacts caused on the comparability of information between companies and between periods for the same company as a result of the non-recognition of inflationary effects in accounting statements due to the cessation of monetary correction in Brazil?

According to Porto (1998, p. 136), "inflation is a serious and relevant problem within the Brazilian economic setting". This proposition has also been shown to be true in the current economic context, since when compared to the inflation of developed countries, the Brazilian rate of price variation has been shown to be expressively higher. This is a macroeconomic problem that has been the object of discussions since 1995, the first full year after the Plano Real (implemented in July of 1994), which argue for the need to present accounting statements in constant purchasing power currency.

Various researchers, such as Ambrozini (2006), Ayres, Mignoni, Silva, and Szüster (2011), Gabriel, Assaf, and Corrar (2005), and Santos (1980), have claimed that the non-recognition of inflation in accounting has hampered the comparability of information. This article intents to contribute to the topic of "absence of monetary correction" by carrying out an empirical analysis of the qualitative characteristic of comparability of information since the veto on monetary correction, in 1996, until 2016. 


\section{THEORETICAL FRAMEWORK}

\subsection{Accounting Information Users, Comparability, and Inflation}

Hendriksen and Van Breda (1999) observe that one of the questions frequently addressed by Accounting Theory is the difficulty in defining the main group of users. Each group is formed of various decision-making agents. With respect to this, Iudícibus (2010) states that besides having to serve the general interests of each group, accounting information should fulfill the individual needs of each one of the agents. According to the author, these users include: shareholders, creditors in general, government entities, employees in general, and middle and senior management.

Currently, Basic Conceptual Pronouncement R1 (2011) restricts the users of accounting information elaborated under their conceptions to only three: (i) investors (existing and potential), (ii) creditors of loans, and (iii) other creditors. This pronouncement also emphasizes that other users may demand information of an accounting nature, providing that for these cases various additional reports to those elaborated are prepared in accordance with the guidelines of the pronouncement.

Martins, Gelbcke, Santos, and Iudícibus (2013) remind us that the Transition Tax Regime (TTR), adopted by Brazil during the convergence of the Brazilian accounting standards with the international standards, enabled the processing of separate information from that of the corporate accounting to attend to the tax authorities, without adversely affecting the information directed at investors and creditors.

Basic Accounting Pronouncement - R1 (2011) also discusses the qualitative characteristics of accounting information, including comparability of information, which foresees comparisons between different companies and between periods for the same company.

Specifically with regards to this characteristic, there are currently various articles that have been developed in the period after convergence between the local standards and the international standards. Franco et al. (2011), Kang (2012), Reina et al. (2014), and Yip and Young (2012), for example, verified an increase in the comparability of the accounting reports of the companies analyzed in their studies after the unification of the practices for recognizing economic events.

It is important, however, to take another question into consideration: when values are compared that have been measured at historical cost, that is, in currencies with different purchasing powers, there is a disparity in monetary equivalence. Thus, despite the convergent accounting standards guaranteeing unified accounting practices in different countries, there may be distortions in the information compared due to inflation and accounting statements that are exempt from its effects.

Krugman and Wells (2007) explain inflation by taking a worker's salary as the basis. According to the authors, over time there is a natural increase in the amounts perceived by that worker. However, the increase observed is only nominal, since simultaneously to this increase, and due to various policies adopted in an economy, there is a rise in the levels of prices practiced. The authors state that "when this level of price increases, we say that the economy experiences inflation" (Krugman \& Wells, 2007, p. 478).

From a financial viewpoint, inflation is treated together with the concept of interest, and consequently, real return on investments and real cost of financing. In a pioneering study, Fisher (1930) demonstrated the relationship between inflation and interest rate, indicating that a one unit increase in inflation in an economy produces a proportionate increase in the interest rate (Fisher Effect).

Besides the association with interest rate, Phillips (1958) related inflation with unemployment rate, by demonstrating that as the rate of unemployment increases, the rate of inflation falls; when the rate of unemployment undergoes an inflexion, the rate of inflation is pushed upwards (Phillips Curve).

Figure 1 shows the cumulative inflation rate between 1996 and 2016 for some countries classified by the International Monetary Fund (IMF) as advanced economies against inflation in Brazil, a country classified as an emerging market and developing economy. 


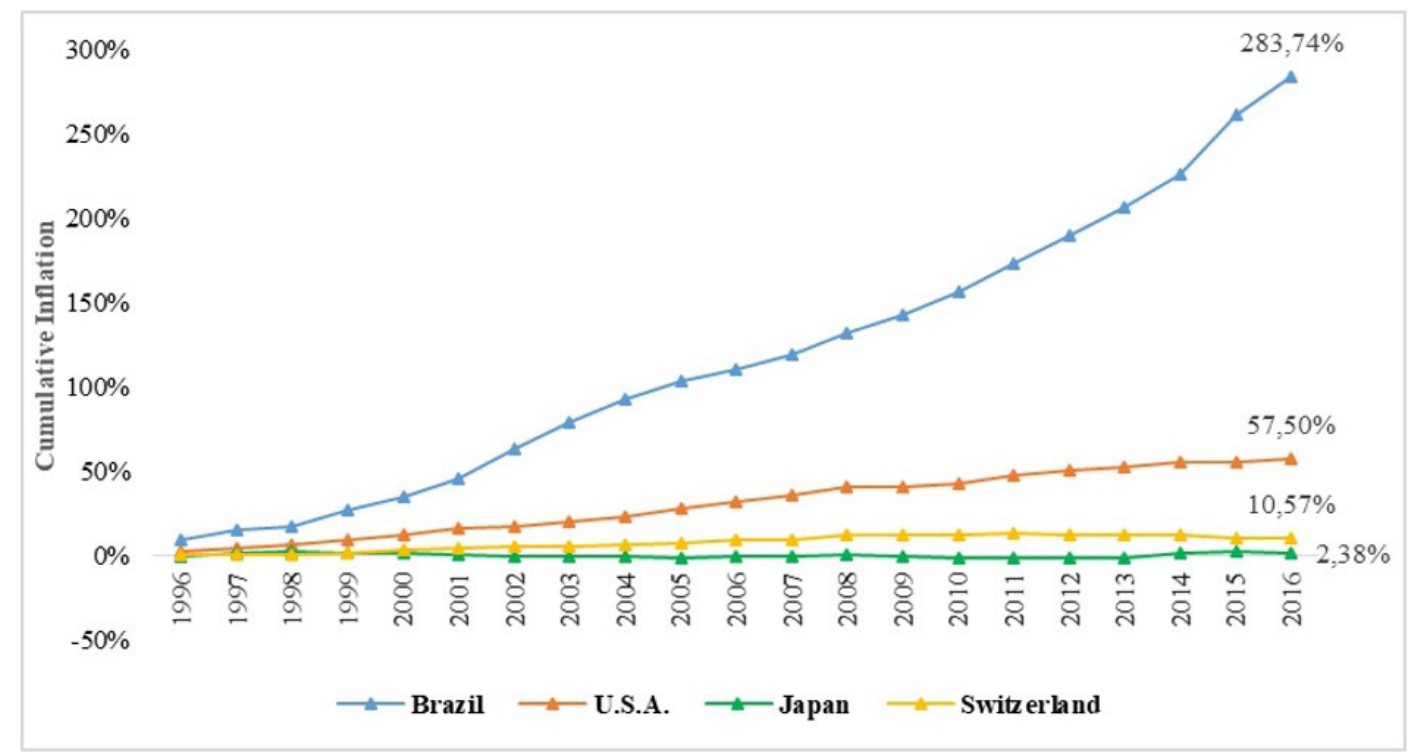

Figure 1 Graph of cumulative inflation of Brazil, United States, Japan, and Switzerland between 1996 and 2016 Source: Elaborated by the authors based on IBGE (2017a) and International Monetary Fund (IMF 2017).

Figure 1 clarifies the expressiveness of differences between the inflation of Brazil and the inflation of advanced economies. Japan, a country that presented a cumulative rate between 1996 and 2016 of around 2\%, shows the most notable of the differences, with the Brazilian rate being 119.2 times the Japanese one. If Switzerland's cumulative inflation for the same period is considered, it is observed that the Brazilian rate is 27 times the rate of that country. In a third comparison, taking the cumulative inflation of the United States as a basis, although the difference is smaller, it still remains expressive: the inflation of Brazil represents 4.9 times the US inflation.

\subsection{Monetary Correction: the Brazilian Experience}

Despite the fact that the current Brazilian accounting legislation establishes historic cost as the basis for measuring economic events, between the 1950s and 1990s, tools known as "monetary correction" were developed and institutionalized in the country, the aim of which was to promote adjustments to accounting statements to account for the effects of inflation.

In 1958, Act n. 3,470 (1958) enabled the correction of the costs of acquiring property, plant, and equipment with a counter entry reflecting an increase in share capital. This procedure was carried out between the year of acquiring the good and December $31^{\text {st }}$ of the second year of each two years, and the variation in assets could be offset by losses. The correction of property, plant, and equipment became obligatory in 1964, via Act n. 4,357 (1964), with the calculation and collection of income tax being based on the value of the correction, except if the taxpayer opted to acquire National Treasury Bonds with a maturity greater than five years and whose value was double the tax owed.

As highlighted by Santos and Ribeiro (2014), some other important regulatory events related to the effects of inflation in the country and to monetary correction marked the 1960s until the middle of the 1970s, such as the promulgation of Decree-Law n. 62, of November $21^{\text {st }}$ of 1966, which authorized the correction of net equity, credits, and obligations - a prelude to the practice that would be improved by Act n. 6,404 (1976) - and of Decree-Law n. 1,452 of March 30 th of 1976, which granted benefits to private Brazilian companies that took out long term loans with financial institutions controlled by the Government aimed towards carrying out priority projects for the country's economy, whose value corresponded to the portion surplus to the $20 \%$ monetary correction rate, and which was used as credit for payment of the installments due in the corresponding year.

Act n. 6,404 (1976) established the BSMC, which foresaw the correction of permanent asset accounts, with a counter entry in revenue, and of net equity accounts, whose counter entry was recorded in expenses in the result for the period. This thus resulted in the presentation of almost all the items in the balance sheet in constant purchasing power currency, since these groups of accounts were the most representative of the non-monetary elements of organizations. The net value of the monetary correction should be taxed via income tax when revenue was greater than expenses, or deducted from taxable income in the opposite case. 
The great advance in the quality of the accounting statements drawn up in accordance with the corporate law of 1976 was made viable via the simplistic way of recognizing the inflationary effects foreseen by this legislation (Porto, 1998). As a counterpoint to this practicality, Martins (1979) argues that one of the flaws of the BSMC was the presentation of the corrections of permanent assets and of net equity grouped into a single line of the income statement for the period, making it difficult to understand the real meaning of the monetary correction, which represented the real increase or decrease in company equity.

Another negative point of BSMC, according to Feitosa (2002), Gabriel et al. (2005), and Martins (1979), lay in the fact that it did not foresee the correction of all non-monetary items presented in the balance sheet (for example, prepaid expenses and inventory). This negative point became relevant over time, given the expressive increase in the inflation rate in Brazil, which enhanced the distortions in the accounts with less representativeness in the balance (for example, prepaid expenses) or with short term rotativity (for example, inventory).

Due to the constant rise in the inflation rate in the country, in 1987 the CVM issued CVM Instruction n. 64 (1987) with a view to improving the quality of information via additional financial statements to those drawn up based on corporate law. From then, companies prepared their accounting statements in accordance with the CMI methodology, which consisted of "producing accounting statements in a single currency for all items composing those statements, as well as showing the effects of inflation on each account" (Martins et al., 2013, p. 799).

The CMI system developed in Brazil became widely known throughout the world. Barbieri and Santos (1996) note that as a result of the Intergovernmental Working Group of Experts on International Standards of Accounting and Reporting (ISAR GROUP), in a meeting held in 1989 the United Nations (UN) recognized the legitimacy of the full correction method due to its high qualitative content. The International Accounting Standards Committee (IASC), also a participant in the meeting, had a favorable opinion of the method developed in Brazil, indicating it as the most advanced one that it had seen up until them (Barbieri \& Santos, 1996).

In 1994, the Plano Real adopted a series of measures to reduce inflation in the country, which in previous periods had presented a rising curve, reaching 2,477.15\% per year in 1993, based on the IPCA (IBGE, 2017b). Unlike the preceding proposals, such as that of the Plano Verão, the Plano Real was successful in its aim. Once the economy was stabilized following the previous backdrop of hyperinflation, via Act n. 9,249 (1995) the legislator established the end of the practice of monetary correction in Brazil. Martins et al. (2013, p. 799) vehemently regretted this legal decision, stating that "all the advances made by Act n. 6,404/76 were thrown away by Act n. 9,249/95".

In line with what was laid out in Act n. 9,249 (1995) regarding the veto on $\mathrm{BSMC}$, the CVM issued CVM Instruction n. 248 (1996), making the presentation of additional accounting statements optional in accordance with the CMI methodology.

With the end of monetary correction in Brazil, various studies have sought to demonstrate that inflation not recognized in accounting statements has continued to cause substantial impacts on the information reported by companies. Melo et al. (2012), for example, verified that the absence of monetary correction caused differences in the corrected net equity, property, plant, and equipment, net income, and return on equity (ROE) of electrical energy companies evaluated in their study in relation to the same historical items, which reached 142.47, 81.79, -67.16 , and $-76.02 \%$, respectively, in 2009 . The authors indicate that abstention from the practice of monetary correction leads to incomplete and distorted accounting statements.

In a study applied to companies from the food and drinks, commerce, electrical energy, chemical, siderurgy and metallurgy, and textile sectors, in the period covering 1996 to 2002, Salotti et al. (2006) observed statistical differences between the corrected rates of liquidity, return, and indebtedness and the same historical rates, reinforcing the fact that the analysis of the information by their users may be affected when the value of money over time is ignored.

In his study, Feitosa (2002) stressed that the problems of the absence of monetary correction transcend the Brazilian setting, as since the end of the practice, Brazilian companies that trade on the New York Stock Exchange and, therefore, are obliged to present information in accordance with the United States Generally Accepted Accounting Principles (US GAAP), have been disclosing information converted into foreign currency (US dollars) at historical values, thus giving rise to differences in relation to the real economic values on the date of presentation of this information.

Santos (2002) carried out an empirical study for 1996, 1997, and 1998 in which the net income of some Brazilian companies adjusted using the CMI methodology is compared with corporate net income. The author stresses that although more attenuated variations were observed for some companies, which may cause some accounting professionals to refute the importance of 
monetary correction in a non-hyperinflationary economic setting, the inflation in the period also caused material differences between the net income calculated using the CMI methodology and corporate net income. Copene, for example, recorded a $791 \%$ variation in 1998 , while Hering calculated a $122.8 \%$ difference in the same year.

Porto (1998) summarized the negative points of not applying monetary correction, one of the main ones being the undervaluation of net income in situations in which the correction of permanent assets exceeds the correction of net equity and overvaluation of this indicator when the opposite situation occurs, a treatment that can lead to a surcharge in the payment of taxes and distribution of dividends calculated using unreal income.

Regarding the impact of the absence of monetary correction of accounting statements on the distribution of dividends, it is important to highlight that the effect can be both prejudicial to shareholders in the case of undervalued income, which generates a lower distribution of dividends, and prejudicial to the financial health of companies when income is overvalued, which is a scenario that produces a greater distribution in relation to the real value due considering the purchasing power of the currency (Ambrozini, 2006; Klann, Souza \& Beuren, 2007).

Currently, there is an international standard that discusses the treatment of accounting statements of companies operating in hyperinflationary economies: International Accounting Standard 29 (IAS, 2009) Financial Reporting in Hyperinflationary Economies. This standard, however, limits its applicability only to when cumulative inflation in three consecutive years reaches $100 \%$. In light of the Brazilian accounting practices after convergence with the international standards, CPC Technical Pronouncement 43 (R1) - Initial Adoption of CPC Technical Pronouncements 15 and 41 (2010) states that no rule corresponding to this topic was issued in the country due to the inapplicability in the current economic setting and the history of an advanced system of monetary correction adopted in Brazil.

The Federal Accounting Council (CFC), in turn, took a favorable position regarding the updating of statements only when inflation reached $100 \%$ in three years, the same rate foreseen in the international standard (CFC Resolution n. 900, 2001).

In 2010, however, CFC Resolution n. 1,282 (2010) revoked the 2001 resolution. At the same time, it altered the principal of recording by original value, establishing that this is liable to variations over time. These variations include an alteration in the purchasing power of the currency, which in turn requires an adjustment of the accounting statements for the effects of inflation.

In CVM Guiding Opinion n. 29 (1996, p. 2), the CVM highlights that although BSMC was ceased by Act n. 9,249 (1995) and CMI became optional via CMV Instruction n. 248 (1996), “open companies should assess the importance of this information, including for comparative analysis purposes, and its disclosure, in order to more fully meet the demands of the market". That is, the CVM itself recognizes that information exempt from the recognition of inflationary effects may distort the comparability of the information.

Researchers who discuss the non-recognition of inflation in accounting statements and the comparability of information are verified in the literature. Gabriel et al. (2005), for example, argue that in order for comparisons to be made regarding their evolution of equity, companies should take into consideration the effects of inflation, at least for management purposes. Ayres et al. (2011) argue that high inflation rates compromise the comparability of information. According to Ambrozini (2006), the absence of monetary correction confuses the comparability of the information reported by companies between different periods and the use of a general price index (inflation rate) improves the measurement of income, enabling the comparability of results. For Santos (1980), a change in price levels in an economy creates, over time, noncomparable information from companies. Despite contributing to the subject, the studies do not specifically examine the "inflation/comparability" perspective. Thus, this article aims to explain, empirically, the problem of the absence of monetary correction with regards to the comparability of information. 


\section{METHODOLOGICAL PROCEDURES}

\subsection{Study Typology and Sample}

Regarding its aim, the study is characterized as descriptive, quantitative with respect to the approach to the problem, and documentary in relation to the data collection procedures (Gil, 2010).
The sample was composed of 12 companies from the siderurgy and metallurgy subsector listed on the São Paulo Stock, Commodities, and Futures Exchange (BM\&FBOVESPA), thus characterizing a non-probability sample. Table 1 lists the component companies of the sample.

Table 1

Component companies of the sample

\begin{tabular}{lccc}
\hline \multicolumn{1}{c}{ Company } & Availability of data & Company & Availability of data \\
\hline Cia. Ferro Ligas Bahia Ferbasa S.A. & 1995 to 2016 & Metalúrgica Gerdau S.A. & 1995 to 2016 \\
\hline Cia. Siderúrgica Nacional S.A. & 1995 to 2016 & Panatlântica S.A. & 1995 to 2016 \\
\hline Fibam Cia. Industrial S.A. & 1995 to 2016 & Paranapanema S.A. & 1995 to 2016 \\
\hline Gerdau S.A. & 1995 to 2016 & Siderúrgica J. L. Aliperti S.A. & 1997 to 2016 \\
\hline Mangels Industrial S.A. & 1995 to 2016 & Tekno S.A. Indústria e Comércio S.A. & 1997 to 2016 \\
\hline Metalúrgica Duque S.A. & 1997 to 2013 & Usinas Siderúrgicas de Minas Gerais S.A. & 1995 to 2016 \\
\hline
\end{tabular}

Source: Elaborated by the authors.

The choice of companies from this subsector is warranted due to its representativeness in the Brazilian economy and its international market share. Data from the World Steel Association (2017) indicate that Brazil produced 30.2 million tons of steel in 2016, putting it in ninth position among 66 countries in the world production ranking. It is worth highlighting that $69 \%$ of total production is derived from Asia (China, Japan, and India are, in that order, the world leaders in terms of production, with $808.4,104.8$, and 96.6 million tons, respectively), which means Brazil stands out in relation to the other member countries of the association. Regarding production in South America, Brazil leads the ranking, with the second and third places for the continent being occupied by Argentina (4.1 million tons) and Colombia (1.3 million tons), with numbers way below that of Brazilian production.

The study took into consideration the period from 1996 (first year in which the accounting statements were presented by the companies exempt from inflationary effects) until 2016 (last year for which there are published accounting statements up to the date of the research). Despite the differences between the accounting practices adopted in Brazil up to 2001 and the accounting practices that went on to be adopted in the period after convergence with the international accounting standards from 2008 onwards, which caused impacts on the comparability of the accounting information on initial adoption, Basic
Conceptual Pronouncement - R1 (2011, p. 19) accepts the loss in comparability of information (as a qualitative characteristic of improved accounting information) in favor of the relevance or faithful representation (as fundamental qualitative characteristics of accounting information), stating that "the temporary reduction in comparability as a result of the prospective application of a new accounting-financial standard can be advantageous for the improvement of relevance or faithful representation in the long term". This admissibility therefore supports the adoption of the period from 1996 to 2016 for carrying out the research.

The consolidated accounting statements of the companies were obtained using the Economatica software. The database is fed by the standardized financial statements (SFS) filed by the companies with the CVM. For the cases in which there was resubmission of accounting statements (spontaneous or compulsory), the resubmitted versions were considered. In 1995, Cia. Siderúrgica Nacional S.A., Gerdau S.A., and Usinas Siderúrgicas de Minas Gerais S.A. presented individual statements. For these companies and period, the individual accounting statements were considered.

\subsection{Procedures for Recognizing Inflation}

Having observed the limitation that in order to apply the CMI additional data are needed that are not available 
in the accounting statements disclosed by companies, such as the date of acquisition of inventories (Martins et al., 2013), given their heightened rotativity, in the study a systematic of the BSMC was employed, which according to Feitosa (2002) and Porto (1998) is seen as a simple and effective methodology in non-hyperinflationary economies, with an approximate effect to the CMI. BSMC was also used by Ambrozini (2006), Gabriel et al. (2005), and Melo et al. (2012).

The index used for the correction was the IPCA published by the IBGE, seen as being the official price variation index adopted by the Government in order to compare with the target and the inflation ceiling in the country, given its methodological reliability, relevance, and robustness. This index was also employed in the study by Melo et al. (2012).

The BSMC was carried out in accordance with the approximating procedures adopted by Ambrozini (2006) and Melo et al. (2012), with some adaptations, as detailed below:

- Monetary correction of property, plant, and equipment, intangible, and deferred asset (revoked by the Brazilian financial accounting law): application of the inflation rate for the year $(t)$ over the corrected balance from the previous year $(t-1)$ and of the weighted average inflation rate for the year $(t)$ over the variation in the historical balance for the year $(t)$ in relation to the previous year $(t-1)$, with the result being recorded as an increase in the asset with a counter entry in revenue. In addition, incremental depreciation, amortization, and exhaustion expenses resulting from inflationary effects were calculated. This procedure was carried out in order to reflect in the income for the period the real values of expenses if the assets that gave origin to them had been monetarily corrected. These complementary expenses for the year $(t)$ were calculated by applying, over the corrected balance from the previous year $(t-1)$, the average rate of depreciation, amortization, and exhaustion for the year $(t)$, and from this result the historical expense recorded in the year $(t)$ was deducted. The rate was estimated as the ratio between the historical depreciation, amortization, and exhaustion expense related to the year for which the correction was carried out $(t)$ and the historical balance for the assets in the previous year $(t-1)$.

- Monetary correction of net equity (NE): the monetary correction of net equity was carried out in the following way:

\footnotetext{
monetary correction of $N E_{(t)}=$ (historical balance for the $N E$ for the year ${ }_{(t)}-/+$ income or loss

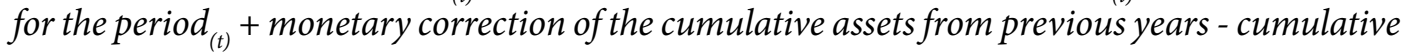
incremental depreciation, amortization, and exhaustion from previous years $-/+$ taxes on the result of cumulative monetary correction from previous years) $\times$ rate of inflation for the year ${ }_{(t)}$
}

The calculation was carried out like this with the aim of not only correcting the historical balance for the net equity for year $(t)$, but also to capture the impacts of the correction from previous years, whose values accumulate in net equity (Ambrozini, 2006, p. 81). It is important to highlight that the result for the period was excluded from the balance for net equity in order not to carry out a correction of the result for the period itself, a procedure also adopted by Ambrozini (2006, p. 81). In addition, the effect of the cumulative monetary correction for net equity in previous periods was also not considered, since, as is highlighted by Martins (2004), the correction of net equity causes an increase in the corrected account against an expense in the result for the period. As the result for the period is directed to the cumulative income or loss account ("income reserves" in the case of a positive result for joint-stock companies) and this value is impacted on by the expense with the correction of the net equity accounts, whose counter entry is the increase itself in the net equity accounts that were corrected, the effect is offset intragroup; that is, the final impact on the group is null. Therefore, the actual variation in net equity derived from the result of the BSMC corresponds exactly to the value calculated in the correction of assets, which reflects an increase in the equity account with a counter entry in revenue, which in turn generates an actual increase in net equity.

Due to its permanent character, the "investments" subgroup is also subject to BSMC. However, the correct procedure for this subgroup requires the monetary correction of the individual accounting statements of those investees in order for, only then, the investor to reflect in their assets, via the equity equivalence (EE) method, the results and other mutations in the equity of the investee with the inflationary effects recorded for them. Given the unavailability of the individual accounting statements of the investees, the decision was made to not correct the "investments" subgroup, this treatment thus constituting a limitation of the research. 
The weighted average annual rate of inflation was used to correct the variations in the asset balances, since these variations did not form exclusively at the start of the year $(t)$, but instead over the months. The average rate was calculated by weighting the inflation for the month by the percentage of participation of that month in relation to the total quantity of months of the year. Thus, the weighting factor $12 / 12(100 \%)$ was considered for the inflation for January, 11/12 (91.67\%) for the inflation for February, 10/12 (83.22\%) for the inflation for March, and so on successively.

The corrected balance for property, plant, and equipment, intangible, and deferred asset (revoked by the Brazilian financial accounting law) in the year $(t)$ is composed in the following way:

corrected balance for property, plant, and equipment, intangible, and deferred asset (revoked by the Brazilian financial accounting law $)_{(t)}=$ previous corrected balance $(t-1)+($ historical balance in the year ${ }_{(t)}$ - historical balance in the previous year $\left.{ }_{(t)}\right)+$ monetary correction of the assets in the year ${ }_{(t)}$ - incremental depreciation, amortization, and exhaustion in the year ${ }_{(t)}$

The corrected balance for the net equity in the year $(t)$ is given by the following equation:

corrected balance for $\mathrm{NE}_{(t)}=$ historical balance for $\mathrm{NE}$ in the year ${ }_{(t)}+$ monetary correction of the assets accumulated from previous years + monetary correction of the assets in the year ${ }_{(t)}$ - incremental depreciation, amortization, and exhaustion accumulated from previous years - incremental depreciation, amortization, and exhaustion in the year ${ }_{(t)}+/$ - taxes on the result of monetary correction accumulated from previous years +/- taxes on the result of monetary correction in the year ${ }_{(t)}$

The final impact on the net income (loss) derived from the adjustments for inflationary effects is the result of the difference between the revenue with BSMC derived from the adjustments of assets and the expenses with BSMC derived from the adjustments of net equity and incremental depreciation, amortization, and exhaustion expense. The effects of a $34 \%$ rate of taxation, for income tax and social security, over the values of the adjustments were recorded, with the taxes on revenue with BSMC corresponding to an expense and the taxes on the expense with BSMC and incremental depreciation, amortization, and exhaustion expense corresponding to a revenue.

It is worth highlighting that, for some companies in the sample, corrected accounting statements related to 1995 (the last year with a recorded monetary correction) were not available in the Economatica database (Table 1), whose balances were the starting point for the monetary correction from 1996 onwards. For these cases, they were corrected using the annual rate of inflation of the historical balances related to the first year in which the statements were available (Table 1) and, for the following years, the correction was carried out in accordance with the methodology mentioned.

\subsection{Study Variables}

Regarding the variables considered for the empirical evaluation of the impacts of the absence of monetary correction, three indicators were used that have net income or net equity or assets in their calculation, these components being subject to the effects of the change in the purchasing power of the currency. The indicators analyzed are: net income (pure and simple), ROE, and ROA.

In relation to net income, Hendriksen and Van Breda (1999) and Malacrida (2009) indicated the existence of the predictive power of income for future cash flows. Stroeher and Freitas (2008) verified net income as an important tool in the decision-making process. Santos (1980), in turn, confirms the informational losses to investors caused when the effects of the variation in price levels on income are not considered.

ROE is a classic indicator of return obtained based on accounting data. For Gabriel et al. (2005, p. 44), "it is one of the main measures of return that identify the overall results earned by managers from the management of own and third party resources, to the benefit of shareholders". 
From the perspective of stock market players, Campos, Lamounier, and Bressan (2012) verified a relationship between ROE and market returns on shares, suggesting that investment decisions take the indicator into account. According to Assaf (2017), ROE is obtained by dividing net income for the period by net equity. Also according to the author, it is usual to use average net equity, excluding the net income for the period from it, since this generally composes it. Thus:

$$
R O E=\frac{N I}{\left(\frac{N E_{t}+N E_{t-1}}{2}\right)-N I}
$$

in which $N I$ means net income for the period, $N E_{t}$ expresses the net equity for the period, and $N E_{t-1}$ represents the net equity from the previous period.

Gallon, Silva, Toledo, and Hein (2009) claim that ROA is a frequently used indicator in investors' evaluations of companies. According to Perez and Begalli (2015, p. 325), ROA "indicates the return on total assets independent of their origin, whether from owners (own capital), from the company's operations, or from third parties (third party capital). It shows the return on the total resources administered by the company. The higher, the better."

Its calculation consists of the ratio between the company's net income and total assets (Gallon et al., 2009). Algebraically:

$$
R O A=\frac{N I_{t}}{T A_{t}}
$$

in which $N I_{t}$ means net income for the period and $T A_{t}$ represents the company's total assets in the period.

Corrected total assets were obtained by summing the companies' historical total assets to the difference between the corrected assets eligible for monetary correction and the historical assets eligible for monetary correction.

The following companies presented a loss and negative net equity: Paranapanema S.A. (2003, 2005, and 2007), Mangels Industrial S.A. (2013, 2014, and 2015), and Fibam Cia. Industrial S.A. (2016). The same behavior was also observed in the study from Salotti et al. (2006). These authors highlight that the performance indicators for companies in these conditions should be ignored, since the relationship between loss and negative net equity produces a positive result, without any sense in this situation. Therefore, the ROE for the companies and periods mentioned was not calculated. Due to this particularity and the unavailability of data for some periods (Table 1), the quantities of companies/variables in the study are the following:

- Net income and ROA: nine companies in 1996, 12 from 1997 to 2013, and 11 companies from 2014 to 2016;

- ROE: nine companies in 1996, 10 in 2014, 2015, and 2016, 11 in 2003, 2005, 2007, and 2013, and 12 companies in the other periods.

\subsection{Research Hypothesis}

Having gathered the historical and monetarily corrected data, in order to obtain an answer to the research question, six hypotheses were elaborated (Table 2) based on the two conceptual axes of comparability, namely, (i) between companies and (ii) between periods for the same company, and three performance indicators, which are: (i) net income, (ii) ROE, and (iii) ROA.

The construction of the parameters applicable to the hypothesis tests took into consideration the possibility of existence of a difference in comparability when monetarily corrected values are used instead of historical values. Due to the null hypothesis assuming equality of the parameters tested, the comparison indices that will indicate the acceptance or rejection of this hypothesis are given by:

$$
I_{\text {comp }}=\frac{C V_{x} / C V_{y}}{H V_{x} / H V_{y}}
$$

$$
I_{t e m p}=\frac{C V_{t} / C V_{t-1}}{H V_{t} / H V_{t-1}}
$$

In expression 6 and 7, $I_{\text {comp }}$ (index of comparability between companies) represents the parameter for the test of comparability between companies and $I_{\text {temp }}$ (temporal comparability index) the parameter for the test of comparability between periods (temporal). $\mathrm{CV}$ and $\mathrm{HV}$ mean the corrected variable and the historical variable, respectively, in which by variable what is understood is net income, ROE, and ROA. The letters $x$ and $y$ represent two companies, $x$ and $y$, respectively. The letter $t$ denotes the current period and $t-1$ is the previous period.

If both comparison indices (corrected and historical) are equal, the ratio between them $\left(I_{\text {comp }}\right.$ for comparability between companies and $I_{\text {comp }}$ for comparability between periods) will result in 1, which enables it to be inferred that the comparison indices do not present distortions 
when obtained using corrected instead of historical data. In contrast, the more this ratio distances itself from 1 , the more evident it becomes that the information presents distortions in comparability, if the effects of inflation are not considered. Thus, as shown in Table 2 , the following null $\left(\mathrm{H}_{0}\right)$ and alternative $\left(\mathrm{H}_{\mathrm{a}}\right)$ hypotheses were formulated.

Table 2

Research hypotheses

\begin{tabular}{|c|c|c|c|c|}
\hline \multirow{2}{*}{$\begin{array}{l}\text { Prefix of the null hypotheses }\left(\mathbf{H}_{\mathbf{0}, \mathbf{x}} \mathbf{~}^{\mathbf{a}}\right. \\
\text { The qualitative characteristic of comparability of the information } \\
\text { between companies is not distorted by the absence of monetary } \\
\text { correction of the accounting statements observing... }\end{array}$} & \multicolumn{3}{|c|}{$\begin{array}{l}\text { Suffix of the null hypotheses and } \\
\text { number of the hypothesis }\end{array}$} & \multirow{2}{*}{$\begin{array}{l}\text { Statistical form } \\
\begin{array}{l}\mathrm{H}_{0}: \bar{I}_{\text {comp }}=1 \\
\mathrm{H}_{\mathrm{a}}: \bar{I}_{\text {comp }} \neq 1\end{array}\end{array}$} \\
\hline & $\begin{array}{c}\text {...net income } \\
\mathrm{H}_{0,1}\end{array}$ & $\begin{array}{c}\ldots \mathrm{ROE} \\
\mathrm{H}_{0,2}\end{array}$ & $\begin{array}{c}\ldots \text { ROA } \\
\mathrm{H}_{0,3}\end{array}$ & \\
\hline $\begin{array}{l}\text { The qualitative characteristic of comparability between periods } \\
\text { for the information is not distorted by the absence of monetary } \\
\text { correction of the accounting statements observing... }\end{array}$ & $\begin{array}{c}\text {...net income } \\
\mathrm{H}_{0,4}\end{array}$ & $\begin{array}{c}\ldots . \mathrm{ROE} \\
\mathrm{H}_{0,5}\end{array}$ & $\begin{array}{c}\ldots \text { ROA } \\
\mathrm{H}_{0,6}\end{array}$ & $\begin{array}{l}\mathrm{H}_{0}: \bar{I}_{\text {temp }}=1 \\
\mathrm{H}_{\mathrm{a}}: \bar{I}_{\text {temp }} \neq 1\end{array}$ \\
\hline
\end{tabular}

a: the letter $x$, in $H_{0, x^{\prime}}$ represents the order number of the hypothesis; $R O A=$ return on assets; $R O E=$ return on equity.

Source: Elaborated by the authors.

\subsection{Data Analysis Methods and Main Limitations of the Study}

Since the populational standard deviation is unknown, in order to evaluate the hypotheses the Student $t$ parametric test was adopted. Anderson, Sweeney, and Williams (2014) point out that large sample sizes (50 or more observations for distributions with many outliers and 30 or more observations for samples with greater symmetry) enable the normality of sample distribution assumption to be discarded to employ the Student $t$ test. Thus, despite the study data not being normally distributed, according to the Kolmogorov-Smirnov normality test, the adoption of the Student $t$ test is viable.

For the analysis of the comparability indices, two hypothesis tests were carried out: in the first all the sample data were considered; in the second the values considered extreme (outliers) were excluded from the sample, using the rule described by Anderson, Sweeney, and Williams (2014, p. 118), which consists of calculating lower and upper limits and excluding the data not fitting within these limits.

As a main limitation of the study, it is worth mentioning the unavailability of analytical data, which would enable more assertive monetary correction calculations, for example, the date of acquisition and retirement of each one of the assets or specific accounts for the net equity eligible for correction.

Another limitation that warrants mentioning is the fact that the results are specifically restricted to publicly traded companies from the siderurgy and metallurgy subsector listed on the BM\&FBOVESPA, and they cannot be extended to closed capital companies or those located in other countries belonging to that subsector, or to companies from other areas of corporate activity.

\section{RESULTS}

Table 3 presents the mean historical and corrected values for net income, ROE, and ROA, as well as the respective percentage variations between both, after the application of monetary correction in the accounting statements.

Table 3

Means of the historical $(H)$ and corrected $(C)$ indicators

\begin{tabular}{ccccccccccc}
\hline \multirow{2}{*}{ Year } & \multicolumn{3}{c}{ Net income $^{\mathbf{a}}$} & \multicolumn{3}{c}{ ROE } & \multicolumn{3}{c}{ ROA } \\
\cline { 2 - 10 } & $\mathbf{H}$ & $\mathbf{C}$ & $\mathbf{\Delta}^{\mathbf{b}}$ & $\mathbf{H}$ & $\mathbf{C}$ & $\boldsymbol{\Delta}^{\mathbf{b}}$ & $\mathbf{H}$ & $\mathbf{C}$ & $\boldsymbol{\Delta}^{\mathbf{b}}$ \\
\hline 1996 & 38 & 42 & 11.50 & 0.0231 & 0.0199 & -13.90 & 0.0150 & 0.0127 & -15.54 \\
\hline 1997 & 46 & 50 & 8.31 & 0.0303 & 0.0220 & -27.47 & 0.0180 & 0.0137 & -24.08 \\
\hline 1998 & 64 & 61 & -3.77 & 0.0326 & 0.0286 & -12.09 & 0.0247 & 0.0213 & -13.79 \\
\hline 1999 & 86 & 107 & 24.90 & 0.0418 & 0.0414 & -0.93 & 0.0251 & 0.0216 & -13.89 \\
\hline
\end{tabular}


Table 3

Cont.

\begin{tabular}{|c|c|c|c|c|c|c|c|c|c|}
\hline \multirow{2}{*}{ Year } & \multicolumn{3}{|c|}{ Net income ${ }^{a}$} & \multicolumn{3}{|c|}{ ROE } & \multicolumn{3}{|c|}{ ROA } \\
\hline & $\mathbf{H}$ & C & $\Delta \%^{\mathrm{b}}$ & $\mathbf{H}$ & C & $\Delta \%{ }^{\mathrm{b}}$ & $\mathbf{H}$ & C & $\Delta \%^{\mathrm{b}}$ \\
\hline 2000 & 232 & 261 & 12.33 & 0.1124 & 0.0956 & -14.92 & 0.0483 & 0.0429 & -11.12 \\
\hline 2001 & 110 & 147 & 33.98 & 0.0693 & 0.0647 & -6.65 & 0.0435 & 0.0368 & -15.32 \\
\hline 2002 & 98 & 187 & 91.92 & 0.1343 & 0.1035 & -22.92 & 0.0507 & 0.0435 & -14.22 \\
\hline 2003 & 404 & 469 & 16.13 & 0.3794 & 0.2075 & -45.30 & 0.0870 & 0.0703 & -19.19 \\
\hline 2004 & 998 & 1,032 & 3.38 & 0.5208 & 0.3178 & -38.98 & 0.1241 & 0.0985 & -20.65 \\
\hline 2005 & 1,045 & 1,016 & -2.80 & 0.3722 & 0.1853 & -50.23 & 0.0891 & 0.0653 & -26.70 \\
\hline 2006 & 926 & 847 & -8.57 & 0.1532 & 0.2155 & 40.64 & 0.0757 & 0.0562 & -25.66 \\
\hline 2007 & 1,234 & 1,160 & -6.01 & 0.3278 & 0.1836 & -44.00 & 0.0881 & 0.0674 & -23.53 \\
\hline 2008 & 1,611 & 1,536 & -4.67 & 0.5924 & 0.1945 & -67.16 & 0.0960 & 0.0742 & -22.75 \\
\hline 2009 & 493 & 389 & -21.07 & 0.1331 & 0.0513 & -61.43 & 0.0407 & 0.0239 & -41.14 \\
\hline 2010 & 759 & 675 & -10.97 & 0.1475 & 0.0692 & -53.06 & 0.0513 & 0.0342 & -33.34 \\
\hline 2011 & 684 & 626 & -8.56 & 0.1067 & 0.0390 & -63.46 & 0.0308 & 0.0174 & -43.49 \\
\hline 2012 & 133 & 46 & -65.54 & -0.0383 & -0.0292 & -23.71 & -0.0058 & -0.0116 & 98.83 \\
\hline 2013 & 313 & 219 & -30.01 & 0.0242 & 0.0115 & -52.48 & -0.0186 & -0.0187 & 0.40 \\
\hline 2014 & 262 & 122 & -53.59 & 0.0143 & -0.0048 & -133.81 & 0.0022 & -0.0070 & -413.68 \\
\hline 2015 & $-1,049$ & $-1,209$ & 15.29 & -0.0264 & -0.0435 & 65.00 & -0.0571 & -0.0518 & -9.28 \\
\hline 2016 & -712 & -899 & 26.30 & -0.0927 & -0.0592 & -36.16 & -0.0814 & -0.0765 & -6.10 \\
\hline All & 385 & 343 & -10.79 & $\mathrm{n} / \mathrm{a}$ & $\mathrm{n} / \mathrm{a}$ & $\mathrm{n} / \mathrm{a}$ & $\mathrm{n} / \mathrm{a}$ & $\mathrm{n} / \mathrm{a}$ & $\mathrm{n} / \mathrm{a}$ \\
\hline
\end{tabular}

a: net income in R\$ million; corrected in relation to historical; $n / a=n o n$-applicable; $R O A=$ return on assets; $R O E=$ return on equity.

Source: Elaborated by the authors.

For some periods it is possible to verify more attenuated distortions. However, in some specific years, there are expressive percentage variations between the means of the corrected indicators and the means of the historical indicators, as is the case of net income in 2001, 2002, 2012, 2013, 2014, and 2016 (33.98, 91.92, -65.54, -30.01, -53.59 , and $26.30 \%$ variations, respectively). Expressive differences are also verified in $\operatorname{ROE}(-67,16,-61,43,-53,06$, $-63,46,-133,81$, and $65 \%$ variations in $2008,2009,2010$,
2011,2014 , and 2015, respectively) and in ROA (-26,70, $-41,14,-33,34 \%,-43,49,98,83$, and $-413,68 \%$ in 2005 , $2009,2010,2011,2012$, and 2014, respectively).

Despite the overall behavior of the indicators expressed by the means, each company, depending on their different equity structures, presented a situation of improvement or worsening in the indicators. Table 4 presents the quantities and percentages of companies for each one of these situations.

Table 4

Quantity and percentage of companies by behaviors of the indicators

\begin{tabular}{|c|c|c|c|c|c|c|}
\hline \multirow[t]{2}{*}{ Year } & \multicolumn{3}{|c|}{$\begin{array}{c}\text { Improvement } \\
n(\%)\end{array}$} & \multicolumn{3}{|c|}{$\begin{array}{l}\text { Worsening } \\
\text { n (\%) }\end{array}$} \\
\hline & Net income & ROE & ROA & Net income & ROE & ROA \\
\hline 1996 & $5(56)$ & $4(44)$ & $5(56)$ & $4(44)$ & $5(56)$ & $4(44)$ \\
\hline 1997 & $4(33)$ & $3(25)$ & $3(25)$ & $8(67)$ & $9(75)$ & $9(75)$ \\
\hline 1998 & $3(25)$ & $3(25)$ & $2(17)$ & $9(75)$ & $9(75)$ & $10(83)$ \\
\hline 1999 & $5(42)$ & $3(25)$ & $5(42)$ & $7(58)$ & $9(75)$ & $7(58)$ \\
\hline 2000 & $6(50)$ & $2(17)$ & $4(33)$ & $6(50)$ & $10(83)$ & $8(67)$ \\
\hline 2001 & $5(42)$ & $3(25)$ & $3(25)$ & $7(58)$ & $9(75)$ & $9(75)$ \\
\hline 2002 & $6(50)$ & $3(25)$ & $5(42)$ & $6(50)$ & $9(75)$ & $7(58)$ \\
\hline 2003 & $5(42)$ & $0(0)$ & $1(8)$ & $7(58)$ & $11(100)$ & $11(92)$ \\
\hline 2004 & $3(25)$ & $1(8)$ & $0(0)$ & $9(75)$ & $11(92)$ & $12(100)$ \\
\hline 2005 & $2(17)$ & $0(0)$ & $1(8)$ & $10(83)$ & $11(100)$ & $11(92)$ \\
\hline 2006 & $0(0)$ & $1(8)$ & $0(0)$ & $12(100)$ & $11(92)$ & $12(100)$ \\
\hline 2007 & $0(0)$ & $0(0)$ & $0(0)$ & $12(100)$ & $11(100)$ & $12(100)$ \\
\hline 2008 & $1(8)$ & $0(0)$ & $0(0)$ & $11(92)$ & $12(100)$ & $12(100)$ \\
\hline
\end{tabular}


Table 4

Cont.

\begin{tabular}{|c|c|c|c|c|c|c|}
\hline \multirow[t]{2}{*}{ Year } & \multicolumn{3}{|c|}{$\begin{array}{c}\text { Improvement } \\
\text { n (\%) }\end{array}$} & \multicolumn{3}{|c|}{$\begin{array}{l}\text { Worsening } \\
\text { n (\%) }\end{array}$} \\
\hline & Net income & ROE & ROA & Net income & ROE & ROA \\
\hline 2009 & $0(0)$ & $1(8)$ & $1(8)$ & $12(100)$ & $11(92)$ & $11(92)$ \\
\hline 2010 & $0(0)$ & $0(0)$ & $0(0)$ & $12(100)$ & $12(100)$ & $12(100)$ \\
\hline 2011 & $2(17)$ & $1(8)$ & $1(8)$ & $10(83)$ & $11(92)$ & $11(92)$ \\
\hline 2012 & $2(17)$ & $5(42)$ & $3(25)$ & $10(83)$ & $7(58)$ & $9(75)$ \\
\hline 2013 & $3(25)$ & $2(18)$ & $2(17)$ & $9(75)$ & $9(82)$ & $10(83)$ \\
\hline 2014 & $1(9)$ & $2(20)$ & $1(9)$ & $10(91)$ & $8(80)$ & $10(91)$ \\
\hline 2015 & $4(36)$ & $4(40)$ & $5(45)$ & $7(64)$ & $6(60)$ & $6(55)$ \\
\hline 2016 & $2(18)$ & $5(50)$ & $7(64)$ & $9(82)$ & $5(50)$ & $4(36)$ \\
\hline All & $59(24)$ & $43(18)$ & $49(20)$ & $187(76)$ & $196(82)$ & 197 (80) \\
\hline
\end{tabular}

$R O A=$ return on assets; $R O E=$ return on equity.

Source: Elaborated by the authors.

The three variables (net income, ROE, and ROA) present more situations of worsening (reduction) when the calculation variables are recorded considering the effects of monetary correction. 2003 and 2010 stand out, in which at least one of the three variables presented a situation of worsening for all the companies.

Table 5 presents the results of the hypothesis test for the net income variable for the comparability between companies.

Table 5

Hypothesis tests for comparability between companies for the net income variable

\begin{tabular}{|c|c|c|c|c|c|c|c|c|c|c|c|c|}
\hline \multirow{2}{*}{ Year } & \multicolumn{6}{|c|}{ Total sample } & \multicolumn{6}{|c|}{ Sample without outliers } \\
\hline & $\mathbf{n}^{\mathbf{a}}$ & $\mathbf{M}$ & SD & CV & $t$ & p-value & $\mathbf{n}^{\mathrm{a}}$ & $\mathbf{M}$ & SD & CV & $t$ & p-value \\
\hline 1996 & 72 & 1.0840 & 0.4505 & 0.4156 & 1.58 & 0.118 & 70 & 1.0433 & 0.3836 & 0.3677 & 0.94 & 0.349 \\
\hline 1997 & 132 & 1.1297 & 0.6251 & 0.5533 & 2.38 & $0.019 * *$ & 121 & 0.9718 & 0.3200 & 0.3293 & -0.97 & 0.334 \\
\hline 1998 & 132 & 0.1120 & 2.5710 & 22.9554 & -3.97 & $<0.001^{* * *}$ & 110 & 0.4975 & 0.8239 & 1.6561 & -6.40 & $<0.001^{* * *}$ \\
\hline 1999 & 132 & 1.1403 & 0.6093 & 0.5343 & 2.64 & $0.009 * * *$ & 126 & 1.0551 & 0.4759 & 0.4510 & 1.30 & 0.196 \\
\hline 2000 & 132 & 0.5230 & 1.4930 & 2.8547 & -3.67 & $<0.001^{* * *}$ & 110 & 1.0352 & 0.3595 & 0.3473 & 1.03 & 0.307 \\
\hline 2001 & 132 & 1.5940 & 4.8550 & 3.0458 & 1.41 & 0.162 & 110 & 0.8068 & 0.6621 & 0.8206 & -3.06 & $0.003^{* * *}$ \\
\hline 2002 & 132 & -0.5930 & 5.1820 & -8.7386 & -3.53 & $0.001^{* * *}$ & 107 & 0.3440 & 1.0810 & 3.1424 & -6.28 & $<0.001^{* * *}$ \\
\hline 2003 & 132 & 0.6931 & 0.8158 & 1.1770 & -4.32 & $<0.001^{* * *}$ & 110 & 1.0362 & 0.2781 & 0.2684 & 1.37 & 0.175 \\
\hline 2004 & 132 & 1.0274 & 0.2411 & 0.2347 & 1.31 & 0.194 & 132 & 1.0274 & 0.2411 & 0.2347 & 1.31 & 0.194 \\
\hline 2005 & 132 & 1.0532 & 0.3420 & 0.3247 & 1.79 & $0.076^{*}$ & 132 & 1.0532 & 0.3420 & 0.3247 & 1.79 & $0.076^{* *}$ \\
\hline 2006 & 132 & 0.4730 & 1.8110 & 3.8288 & -3.34 & $0.001^{* * *}$ & 100 & 0.9775 & 0.3095 & 0.3166 & -0.73 & 0.469 \\
\hline 2007 & 132 & 1.1242 & 0.6209 & 0.5523 & 2.30 & $0.023^{* *}$ & 120 & 0.9660 & 0.2746 & 0.2843 & -1.36 & 0.177 \\
\hline 2008 & 132 & 0.8160 & 5.6000 & 6.8627 & -0.38 & 0.706 & 112 & 0.4495 & 0.8942 & 1.9893 & -6.51 & $<0.001^{* * *}$ \\
\hline 2009 & 132 & -0.3450 & 4.5610 & -13.2203 & -3.39 & $0.001^{* * *}$ & 118 & 0.9348 & 0.4786 & 0.5120 & -1.48 & 0.141 \\
\hline 2010 & 132 & -0.2340 & 3.4340 & -14.6752 & -4.13 & $<0.001^{* * *}$ & 121 & 0.5813 & 0.7918 & 1.3621 & -5.82 & $<0.001^{* * *}$ \\
\hline 2011 & 132 & -0.5400 & 10.2360 & -18.9556 & -1.73 & $0.086^{*}$ & 105 & 0.9001 & 0.7872 & 0.8746 & -1.30 & 0.196 \\
\hline 2012 & 132 & 1.3074 & 1.1296 & 0.8640 & 3.13 & $0.002^{* * *}$ & 121 & 1.0252 & 0.5342 & 0.5211 & 0.52 & 0.605 \\
\hline 2013 & 132 & -1.9890 & 8.4950 & -4.2710 & -4.04 & $<0.001^{* * *}$ & 111 & 0.8747 & 0.6398 & 0.7315 & -2.06 & $0.041^{* *}$ \\
\hline 2014 & 110 & 0.4680 & 1.5590 & 3.3312 & -3.58 & $0.001^{* * *}$ & 106 & 0.3890 & 1.3290 & 3.4165 & -4.73 & $<0.001^{* * *}$ \\
\hline 2015 & 110 & -2.7300 & 12.6200 & -4.6227 & -3.10 & $0.002^{* * *}$ & 94 & 0.9040 & 0.4982 & 0.5511 & -1.87 & $0.065^{*}$ \\
\hline 2016 & 100 & 1.6960 & 2.2670 & 1.3367 & 3.07 & $0.003^{* * *}$ & 90 & 1.0409 & 0.7253 & 0.6968 & 0.53 & 0.594 \\
\hline All & 2636 & 0.3649 & 4.8265 & 13.2269 & -6.76 & $<0.001^{* * *}$ & 2192 & 0.9247 & 0.4559 & 0.4930 & -7.74 & $<0.001^{* * *}$ \\
\hline
\end{tabular}

a: number of observations of $I_{\text {comp }}$ (index of comparability between companies) obtained via equation 6 presented in the methodology section of the study. For the case of the sample without outliers, the data will be excluded in accordance with item 3.5 of the methodology; $C V=$ coefficient of variation; $S D=$ standard deviation; $M=$ mean.

*,**,**: significant at 10,5 , and $1 \%$, respectively.

Source: Elaborated by the authors. 
When the total sample for the net income variable is considered, 1996, 2001, 2004, and 2008 do not present statistical significance. Excluding the outliers, there is statistical significance at $10 \%$ in 2015 , at $5 \%$ in 2005 and 2013 , and at $1 \%$ in $1998,2001,2002,2008,2010$, 2014 , and when all the periods are considered together. Thus, the evidence of significance for a good portion of the periods, both when observing the total sample and excluding the outliers, show that $\mathrm{H}_{0,1}$ should be rejected, leading to evidence of distortions in the comparability of the information between companies when the accounting statements are not corrected for the effects of inflation.

In Table 6, the results of the hypothesis test for the ROE variable are presented regarding comparability between companies.

Table 6

Hypothesis tests for comparability between companies for the return on equity (ROE) variable

\begin{tabular}{|c|c|c|c|c|c|c|c|c|c|c|c|c|}
\hline \multirow{2}{*}{ Year } & \multicolumn{6}{|c|}{ Total sample } & \multicolumn{6}{|c|}{ Sample without outliers } \\
\hline & $\mathbf{n}^{\mathrm{a}}$ & $\mathbf{M}$ & SD & CV & $t$ & p-value & $\mathbf{n}^{\mathrm{a}}$ & $\mathbf{M}$ & SD & CV & $t$ & p-value \\
\hline 1996 & 72 & 1.1185 & 0.5449 & 0.4872 & 1.84 & $0.069 * *$ & 69 & 1.0506 & 0.4443 & 0.4229 & 0.95 & 0.348 \\
\hline 1997 & 132 & 1.1296 & 0.6269 & 0.5550 & 2.37 & $0.019 * *$ & 121 & 0.9701 & 0.3151 & 0.3248 & -1.04 & 0.299 \\
\hline 1998 & 132 & 0.1350 & 2.5310 & 18.7481 & -3.93 & $<0.001^{* * *}$ & 111 & 0.4812 & 0.8526 & 1.7718 & -6.41 & $<0.001^{* * *}$ \\
\hline 1999 & 132 & 1.1403 & 0.6137 & 0.5382 & 2.63 & $0.010^{* * *}$ & 126 & 1.0507 & 0.4646 & 0.4422 & 1.22 & 0.223 \\
\hline 2000 & 132 & 0.5250 & 1.5590 & 2.9695 & -3.50 & $0.001^{* * *}$ & 108 & 0.9626 & 0.3929 & 0.4082 & -0.99 & 0.325 \\
\hline 2001 & 132 & 1.4950 & 4.4560 & 2.9806 & 1.28 & 0.204 & 111 & 0.8099 & 0.7189 & 0.8876 & -2.79 & $0.006^{* * *}$ \\
\hline 2002 & 132 & -0.5870 & 3.4860 & -5.9387 & -5.23 & $<0.001^{* * *}$ & 110 & 0.5147 & 0.9357 & 1.8180 & -5.44 & $<0.001^{* * *}$ \\
\hline 2003 & 110 & 0.6627 & 0.8447 & 1.2746 & -4.19 & $<0.001^{* * *}$ & 90 & 1.0377 & 0.2834 & 0.2731 & 1.26 & 0.211 \\
\hline 2004 & 132 & 0.6510 & 0.9921 & 1.5240 & -4.04 & $<0.001^{* * *}$ & 105 & 1.0021 & 0.2520 & 0.2515 & 0.08 & 0.933 \\
\hline 2005 & 110 & 1.0612 & 0.3696 & 0.3483 & 1.74 & $0.085^{*}$ & 110 & 1.0612 & 0.3696 & 0.3483 & 1.74 & $0.085^{*}$ \\
\hline 2006 & 132 & 0.1870 & 2.3090 & 12.3476 & -4.05 & $<0.001^{* * *}$ & 115 & 0.7407 & 0.8573 & 1.1574 & -3.24 & $0.002^{* * *}$ \\
\hline 2007 & 110 & 1.1858 & 0.7856 & 0.6625 & 2.48 & $0.015^{* *}$ & 101 & 0.9863 & 0.3955 & 0.4010 & -0.35 & 0.729 \\
\hline 2008 & 132 & 1.0600 & 6.5850 & 6.2123 & 0.10 & 0.917 & 111 & 0.3190 & 1.2350 & 3.8715 & -5.81 & $<0.001^{* * *}$ \\
\hline 2009 & 132 & -0.6820 & 5.8580 & -8.5894 & -3.30 & $0.001^{* * *}$ & 119 & 0.9723 & 0.5499 & 0.5656 & -0.55 & 0.584 \\
\hline 2010 & 132 & -0.3620 & 4.0820 & -11.2762 & -3.83 & $<0.001^{* * *}$ & 121 & 0.6046 & 0.8483 & 1.4031 & -5.13 & $<0.001^{* * *}$ \\
\hline 2011 & 132 & -0.8130 & 11.3120 & -13.9139 & -1.84 & $0.068^{*}$ & 105 & 0.8998 & 0.7804 & 0.8673 & -1.32 & 0.191 \\
\hline 2012 & 132 & 1.2159 & 0.8628 & 0.7096 & 2.87 & $0.005^{* * *}$ & 121 & 1.0016 & 0.4479 & 0.4472 & 0.04 & 0.968 \\
\hline 2013 & 110 & -2.0430 & 8.0330 & -3.9320 & -3.97 & $<0.001^{* * *}$ & 91 & 0.8263 & 0.5830 & 0.7056 & -2.84 & $0.006^{* * *}$ \\
\hline 2014 & 90 & 0.3280 & 1.2450 & 3.7957 & -5.12 & $<0.001^{* * *}$ & 90 & 0.3280 & 1.2450 & 3.7957 & -5.12 & $<0.001^{* * *}$ \\
\hline 2015 & 90 & -2.0800 & 10.9900 & -5.2837 & -2.66 & $0.009 * * *$ & 78 & 0.9784 & 0.6979 & 0.7133 & -0.27 & 0.785 \\
\hline 2016 & 81 & 2.5870 & 5.6100 & 2.1685 & 2.55 & $0.013^{* *}$ & 69 & 1.0260 & 0.9770 & 0.9522 & 0.22 & 0.823 \\
\hline Todos & 2489 & 0.3618 & 4.8655 & 13.4480 & -6.54 & $<0.001^{* * *}$ & 2085 & 0.8967 & 0.5403 & 0.6025 & -8.73 & $<0.001^{* * *}$ \\
\hline
\end{tabular}

a: number of observations of $I_{\text {comp }}$ (index of comparability between companies) obtained via equation 6 presented in the methodology section of the study. For the case of the sample without outliers, the data were excluded in accordance with item 3.5 of the methodology; $C V=$ coefficient of variation; $S D=$ standard deviation; $M=$ mean .

*,**,**: significant at 10,5 , and $1 \%$, respectively.

Source: Elaborated by the authors

Regarding the ROE variable, considering all the sample data, there was no statistical significance in 2001 and 2008. Excluding the outliers from the sample, statistical significance is verified at $10 \%$ in 2005 and at $1 \%$ in 1998, 2001, 2002, 2006, 2008, $2010,2013,2014$, and for all the years tested together. Therefore, the evidence obtained enables hypothesis
$\mathrm{H}_{0,2}$ to be rejected, leading to the conclusion that the comparability between companies for the ROE variable is hampered when monetary correction is not carried out.

Table 7 presents the results of the hypothesis test for the comparability between companies considering the ROA variable. 
Table 7

Hypothesis tests for comparability between companies for the return on assets (ROA) variable

\begin{tabular}{|c|c|c|c|c|c|c|c|c|c|c|c|c|}
\hline \multirow{2}{*}{ Year } & \multicolumn{6}{|c|}{ Total sample } & \multicolumn{6}{|c|}{ Sample without outliers } \\
\hline & $\mathbf{n}^{\mathrm{a}}$ & $M$ & SD & CV & $t$ & p-value & $\mathbf{n}^{\mathrm{a}}$ & $\mathbf{M}$ & SD & CV & $t$ & p-value \\
\hline 1996 & 72 & 1.0846 & 0.4535 & 0.4181 & 1.58 & 0.118 & 70 & 1.0434 & 0.3850 & 0.3690 & 0.94 & 0.349 \\
\hline 1997 & 132 & 1.1329 & 0.6418 & 0.5665 & 2.38 & $0.019^{* *}$ & 121 & 0.9668 & 0.3078 & 0.3184 & -1.19 & 0.238 \\
\hline 1998 & 132 & 0.1160 & 2.5000 & 21.5517 & -4.06 & $<0.001^{* * *}$ & 110 & 0.4956 & 0.8280 & 1.6707 & -6.39 & $<0.001^{* * *}$ \\
\hline 1999 & 132 & 1.1458 & 0.6271 & 0.5473 & 2.67 & $<0.009^{* * *}$ & 126 & 1.0552 & 0.4784 & 0.4534 & 1.30 & 0.197 \\
\hline 2000 & 132 & 0.5400 & 1.4260 & 2.6407 & -3.71 & $<0.001^{* * *}$ & 109 & 1.0446 & 0.3366 & 0.3222 & 1.38 & 0.169 \\
\hline 2001 & 132 & 1.5560 & 4.5380 & 2.9165 & 1.41 & 0.162 & 110 & 0.8053 & 0.6723 & 0.8348 & -3.04 & $0.003^{* * *}$ \\
\hline 2002 & 132 & -0.6500 & 5.1940 & -7.9908 & -3.65 & $<0.001^{* * *}$ & 107 & 0.2880 & 1.0670 & 3.7049 & -6.90 & $<0.001^{* * *}$ \\
\hline 2003 & 132 & 0.6966 & 0.8181 & 1.1744 & -4.26 & $<0.001^{* * *}$ & 110 & 1.0395 & 0.2915 & 0.2804 & 1.42 & 0.158 \\
\hline 2004 & 132 & 1.0245 & 0.2282 & 0.2227 & 1.23 & 0.220 & 130 & 1.0139 & 0.2130 & 0.2101 & 0.74 & 0.458 \\
\hline 2005 & 132 & 1.0717 & 0.4053 & 0.3782 & 2.03 & $0.044^{* *}$ & 128 & 1.0374 & 0.3609 & 0.3479 & 1.17 & 0.243 \\
\hline 2006 & 132 & 0.4710 & 1.7590 & 3.7346 & -3.46 & $0.001^{* * *}$ & 119 & 0.9552 & 0.5198 & 0.5442 & -0.94 & 0.349 \\
\hline 2007 & 132 & 1.1712 & 0.7818 & 0.6675 & 2.52 & $0.013^{* *}$ & 121 & 0.9582 & 0.3043 & 0.3176 & -1.51 & 0.133 \\
\hline 2008 & 132 & 0.9890 & 6.8020 & 6.8777 & -0.02 & 0.985 & 114 & 0.3931 & 0.9988 & 2.5408 & -6.49 & $<0.001^{* * *}$ \\
\hline 2009 & 132 & -0.5970 & 5.3580 & -8.9749 & -3.42 & $0.001^{* * *}$ & 118 & 0.9309 & 0.4581 & 0.4921 & -1.64 & 0.104 \\
\hline 2010 & 132 & -0.3530 & 3.8800 & -10.9915 & -4.01 & $<0.001^{* * *}$ & 121 & 0.5793 & 0.7821 & 1.3501 & -5.92 & $<0.001^{* * *}$ \\
\hline 2011 & 132 & -0.7000 & 11.5700 & -16.5286 & -1.69 & $0.093^{*}$ & 103 & 0.8440 & 0.7035 & 0.8335 & -2.25 & $0.027^{* *}$ \\
\hline 2012 & 132 & 1.2384 & 0.9400 & 0.7590 & 2.91 & $0.004^{* * *}$ & 121 & 1.0039 & 0.4619 & 0.4601 & 0.09 & 0.927 \\
\hline 2013 & 132 & -1.7270 & 7.4290 & -4.3017 & -4.22 & $<0.001^{* * *}$ & 111 & 0.8624 & 0.6075 & 0.7044 & -2.39 & $0.019^{* *}$ \\
\hline 2014 & 110 & 0.4610 & 1.4370 & 3.1171 & -3.93 & $<0.001^{* * *}$ & 107 & 0.4250 & 1.2860 & 3.0259 & -4.62 & $<0.001^{* * *}$ \\
\hline 2015 & 110 & -2.2000 & 11.1000 & -5.0455 & -3.02 & $0.003^{* * *}$ & 91 & 0.8547 & 0.4431 & 0.5184 & -3.13 & $0.002^{* * *}$ \\
\hline 2016 & 100 & 1.5320 & 1.8240 & 1.1906 & 2.92 & $0.004^{* * *}$ & 88 & 0.9578 & 0.5468 & 0.5709 & -0.72 & 0.471 \\
\hline All & 2636 & 0.3719 & 4.8257 & 12.9758 & -6.68 & $<0.001^{* * *}$ & 2188 & 0.9320 & 0.4421 & 0.4743 & -7.20 & $<0.001^{* * *}$ \\
\hline
\end{tabular}

a: number of observations of $I_{\text {comp }}$ (index of comparability between companies) obtained via equation 6 presented in the methodology section of the study. For the case of the sample without outliers, the data were excluded in accordance with item 3.5 of the methodology; $C V=$ coefficient of variation; $S D=$ standard deviation; $M=$ mean.

*,**,**: significant at 10,5 , and $1 \%$, respectively.

Source: Elaborated by the authors.

The hypothesis test regarding the comparability between companies for the ROA variable, considering all the sample data, did not present statistical significance for 1996, 2001, 2004, and 2008. When the data without outliers are considered, statistical significance is verified at $5 \%$ in 2011 and 2013 and at 1\% in 1998, 2001, 2002, 2008, 2010, 2014,2015 , and for all the periods tested together. The data therefore reveal that hypothesis $\mathrm{H}_{0,3}$ should be rejected; that is, the absence of monetary correction causes an impact on the comparability between companies for the ROA variable.
Regarding the comparability between periods, due to the fact that the size of the sample is small when only one comparison period in relation to the previous period is observed, no individualized tests were carried out. Thus, the samples were composed of the set of observations of the comparison of the net income, ROE, and ROA variables in the periods 1997 vs. 1996, 1998 vs. 1997,1999 vs. 1998,2000 vs. 1999,2001 vs. 2000 , and so on. The results of the tests are presented in Table 8.

Table 8

Hypothesis tests for comparability between periods

\begin{tabular}{|c|c|c|c|c|c|c|c|c|c|c|c|c|}
\hline \multirow{2}{*}{ Variável } & \multicolumn{6}{|c|}{ Total sample } & \multicolumn{6}{|c|}{ Sample without outliers } \\
\hline & $\mathbf{n}^{\mathrm{a}}$ & $\mathbf{M}$ & SD & CV & $t$ & p-value & $\mathbf{n}^{\mathbf{a}}$ & $\mathbf{M}$ & SD & CV & $t$ & p-value \\
\hline Net income & 234 & 0.6260 & 2.5800 & 4.1214 & -2.22 & $0.028^{* *}$ & 184 & 0.9700 & 0.2337 & 0.2409 & -1.74 & $0.083^{*}$ \\
\hline ROE & 223 & 0.5970 & 2.4670 & 4.1323 & -2.44 & $0.016^{* *}$ & 177 & 0.9390 & 0.2609 & 0.2778 & -3.11 & $0.002^{* * *}$ \\
\hline ROA & 234 & 0.6160 & 2.5260 & 4.1006 & -2.33 & $0.021^{* *}$ & 185 & 0.9546 & 0.2405 & 0.2519 & -2.57 & $0.011^{* *}$ \\
\hline
\end{tabular}

a: number of observations of Itemp (temporal comparability index) obtained via equation (7) presented in the methodology section of the study. For the case of the sample without outliers, the data were excluded in accordance with item 3.5 of the methodology; $C V=$ coefficient of variation; $S D=$ standard deviation; $M=$ mean; $R O A=$ return on assets; $R O E=$ return on equity. *,**, ***: significant at 10,5 , and $1 \%$, respectively.

Source: Elaborated by the authors. 
Regarding the hypothesis tests for comparability between periods, considering the total sample, there is statistical significance for all the variables (net income, ROE, and ROA) at a $5 \%$ level of significance. Excluding the outliers, the net income variable presents statistical significance at $10 \%, \mathrm{ROA}$ at $5 \%$, and the ROE variable presents statistical significance at $1 \%$. The results therefore lead to the rejection of hypotheses $\mathrm{H}_{0,4}, \mathrm{H}_{0,5}$ and $\mathrm{H}_{0,6^{\prime}}$ which implies that there is statistical evidence of a distortion in comparability between periods for the net income, ROE, and ROA variables.

Although no statistical evidence was verified to reject the null hypotheses of comparability between companies is some years, a detailed analysis of the percentage variations between the corrected and historical comparability indices $\left(I_{\text {comp }}\right.$ and $\left.I_{\text {temp }}\right)$ confirm the existence of expressive differences. This analysis is shown in Table 9.

\section{Table 9}

Percentage variations of $I_{\text {comp }}$ (index of comparability between companies) and of Itemp (temporal comparability index) between the corrected and historical ${ }^{2}$ comparability indices - without outliers

\begin{tabular}{|c|c|c|c|c|c|}
\hline \multirow[b]{2}{*}{ Variable } & \multirow[b]{2}{*}{ Description } & \multicolumn{2}{|c|}{ Comparability between companies } & \multicolumn{2}{|c|}{ Comparability between periods } \\
\hline & & $\underset{\text { negative }}{\Delta I_{\text {emp }}}$ & $\begin{array}{c}\Delta I_{\text {emp }} \\
\text { positive }\end{array}$ & $\begin{array}{c}\Delta I_{\text {temp }} \\
\text { negative }\end{array}$ & $\begin{array}{c}\Delta I_{\text {temp }} \\
\text { positive }\end{array}$ \\
\hline \multirow{7}{*}{$\begin{array}{c}\text { Net } \\
\text { income }\end{array}$} & $\mathrm{n}^{\mathrm{b}}$ & 1,243 & 949 & 105 & 79 \\
\hline & Mean (\%) & -36.8 & 30.8 & -17.2 & 15.9 \\
\hline & Minimum (\%) & -137.6 & 0.0 & -78.0 & 0.1 \\
\hline & Q1 (\%) & -49.5 & 9.6 & -22.5 & 5.9 \\
\hline & Q2 (\%) & -26.0 & 23.8 & -10.7 & 11.2 \\
\hline & Q3 (\%) & -11.2 & 45.3 & -4.9 & 20.4 \\
\hline & Maximum $(\%)$ & 0.0 & 117.4 & -0.5 & 58.9 \\
\hline \multirow{7}{*}{ ROE } & $\mathrm{n}^{\mathrm{b}}$ & 1,206 & 879 & 102 & 75 \\
\hline & Mean (\%) & -44.3 & 36.3 & -22.0 & 15.6 \\
\hline & Minimum (\%) & -162.6 & 0.1 & -83.9 & 0.0 \\
\hline & Q1 (\%) & -62.5 & 11.3 & -27.0 & 5.7 \\
\hline & Q2 (\%) & -31.2 & 27.8 & -14.5 & 11.3 \\
\hline & Q3 (\%) & -14.4 & 52.9 & -7.6 & 19.7 \\
\hline & Maximum (\%) & -0.1 & 135.5 & -0.2 & 61.0 \\
\hline \multirow{7}{*}{ ROA } & $\mathrm{n}^{\mathrm{b}}$ & 1232 & 956 & 109 & 76 \\
\hline & Mean (\%) & -35.6 & 30.3 & -18.5 & 15.4 \\
\hline & Minimum (\%) & -133.7 & 0.0 & -81.3 & 0.1 \\
\hline & Q1 (\%) & -47.2 & 9.8 & -23.5 & 5.2 \\
\hline & Q2 (\%) & -24.5 & 23.7 & -11.5 & 10.7 \\
\hline & Q3 (\%) & -11.9 & 44.1 & -5.7 & 20.1 \\
\hline & Maximum (\%) & 0.0 & 114.9 & -0.2 & 58.9 \\
\hline
\end{tabular}

a: not considering the outliers. Considering them, the observed distortions would be even greater; $b=$ observations obtained by adding - 1 to equations $I_{\text {comp }}$ and $I_{\text {temp }}$ and multiplying by 100 to convert into percentages. The sums of the $n$ related to the negative and positive variations confer with the $n$ presented in tables 5, 6, and 7 (for comparability between companies) and 8 (for comparability between periods); ROA = return on assets; $R O E=$ return on equity.

Source: Elaborated by the authors.

The observation of the range between the minimum value and the $2^{\text {nd }}$ quartile of the negative variations for comparability between companies enables it to be inferred that $50 \%$ of the data present percentage variations of between -137.6 and $-26 \%$ for net income, between -162.6 and $-31,2 \%$ for ROE, and between -133.7 and $-24.5 \%$ for ROA. Regarding the positive variations, observing the range between the $2^{\text {nd }}$ quartile and the maximum value, $50 \%$ of the data present percentage variations of between 23.8 and $117.4 \%$ for net income, between 27.8 and $135.5 \%$ for ROE, and between 23.7 and $114.9 \%$ for ROA. These data reinforce the existence of relevant indications of distortions in the comparability of the information between companies due to the absence of monetary correction in the accounting statements.

Regarding the comparability between periods, it is observed that $25 \%$ of the data (range between the minimum value and the $1^{\text {st }}$ quartile) present negative 
values of between -78 and $-22.5 \%$ for net income, between -83.9 and $-27 \%$ for ROE, and between -81.3 and $-23.5 \%$ for ROA. Regarding the positive variations, $25 \%$ of the data (range between the $3^{\text {rd }}$ quartile and the maximum value) present variations of between 20.4 and 58.9\% for net income, between $19.7 \%$ and $61 \%$ for ROE, and between $20.1 \%$ and $58.9 \%$ for ROA. These observations confirm the existence of distortions in the comparability of the information between periods when the monetary correction is not applied, although in a smaller proportion in relation to the comparability between companies.

\section{CONCLUSIONS}

With 21 years having passed since the end of monetary correction in Brazil, even today inflation remains a constantly reported and discussed economic problem in the country. This context revives the need to reflect upon the relevance of the presentation of accounting statements with information that considers variations in the purchasing power of the currency.

Considering Brazilian companies from the siderurgy and metallurgy subsector listed on the BM\&FBOVESPA, in the period covering 1996 to 2016, this study investigated, empirically, what the evidence is of the impacts caused on the comparability of the information reported to investors due to the recording of economic events without the effects of inflation.

In response to the research question, both when all the sample data and when the data without outliers are considered, the results obtained enabled the rejection of the six initially established hypotheses, which foresaw the equality of comparability of historical information and of monetarily corrected information for the net income, ROE, and ROA variables, between companies and between periods. The analyses of the percentage variations between the corrected comparability indices in relation to the historical indices also revealed the existence of considerable distortions, both for the comparability between companies and for the comparability between periods, although the latter was in a lower proportion in relation to the former.

In addition, for some periods very relevant distortions were found between the means of the corrected indicators and the means of the historical indicators, such as in the case of net income in 2001, 2002, 2012, 2013,2014, and $2016(33.98,91.92,-65.54,-30.01,-53.59$, and $26.30 \%$ variations, respectively), of ROE (-67.16, -61.43, -53.06, $-63.46,-133.81$, and $65 \%$ variations in $2008,2009,2010$, 2011,2014 , and 2015, respectively), and of ROA (-26.70, $-41.14,-33.34,-43.49,98.83$, and $-413.68 \%$ in 2005 , $2009,2010,2011,2012$, and 2014, respectively). Thus, the accounting information was very much affected by the absence of monetary correction, with a consequent impact on the decision-making process of its users.
The empirical results support the arguments of Feitosa (2002), Melo et al. (2012), Porto (1998), Salotti et al. (2006), and some of the authors who have sought to demonstrate the informational damage caused by the absence of monetary correction. The findings of the study also reinforce the proposals of Ambrozini (2006), Ayres et al. (2011), Gabriel et al. (2005), and Santos (1980) regarding the existence of impacts on the comparability of information when tools are not adopted to address the inflationary effects on the accounting statements reported to investors. Thus, users could be mistaken when comparing the performance of one specific company with another engaged in similar activities, or when finding an improvement or worsening in performance of a company by comparing information between periods. It is worth noting that the results obtained are conditioned by some limitations, such as the fact that the BSMC was carried out in workarounds, with an approximate effect, given the unavailability of analytical data, as well as the results not being able to be generalized, with them being restricted to publicly traded Brazilian companies from the siderurgy and metallurgy subsector listed on the BM\&FBOVESPA.

In an IASB meeting on April $29^{\text {th }}$ of 2015, the need to review the guidelines of IAS 29 (international standard that discusses the accounting statements of companies operating in hyperinflationary economies) was discussed, such as the reduction in three-year cumulative inflation from 100 to $26 \%$ - approximately $8 \%$ per year - for its applicability. This confirms the concern of the theorists and standard-setting bodies regarding the topic of inflation and accounting in the current economic setting. With regards to this point, this study reinforces the idea that for the Brazilian case annual rates of inflation (IPCA) that went from $1.65 \%$ and presented a mean of $6.64 \%$ in the period from 1996 to 2016, which is lower than the $8 \%$ proposed in the meeting, have been sufficient to generate distortions in accounting statements, confirming the importance of presenting information corrected for inflationary effects.

In summary, after 21 years, even though today the inflationary scenario in Brazil is substantially lower than 
the hyperinflationary scenario experienced in the 1980s and 1990s, discussing the need for accounting recognition of the effects of inflation remains an extremely relevant and pertinent question, since after all one of the fundamental premises of accounting is to produce faithful information, which should most closely reflect the economic reality in which organizations operate.

Having observed (i) the limitation that the results of the study cannot be generalized for all companies, (ii) the existence of variabilities in assets and own capital structures concerning each segment, and (iii) the different inflation rates between countries, it is suggested that future studies apply this study's proposal to other fields of corporate activity and to companies operating in other emerging countries, such as Argentina and Venezuela, in relation to Brazilian companies engaged in similar activities. Another point to be explored by future research is whether the inflationary effects in countries classified as advanced economies, such as the United States, Japan, and Switzerland, although in lower percentages than those observed in emerging economies, cause impacts on the comparability of the information generated by traditional accounting.

\section{REFERENCES}

Ambrozini, M. A. (2006). O impacto do fim da correção monetária no resultado das companhias brasileiras de capital aberto e na distribuição de dividendos: estudo empírico no período de 1996 a 2004 (Master's dissertation). University of São Paulo, São Paulo. Retrieved from http://www.teses.usp.br/ teses/disponiveis/96/96133/tde-05012007-170944/pt-br.php

Anderson, D. R., Sweeney, D. J., \& Williams, T. A. (2014). Estatística aplicada à administração e economia (3rd ed., S. A. Visconti, trad.). São Paulo, SP: Cengage Learning.

Assaf, A., Neto (2017). Valuation: métricas de valor \& avaliação de empresas (2nd ed.). São Paulo, SP: Atlas.

Ayres, R. M., Mignoni, T. C., Silva, P. R., \& Szüster, N. (2011). $\mathrm{O}$ ativo e suas avaliações: a estrutura de mensuração atual reconhece o impacto da flutuação do poder aquisitivo da moeda?Pensar Contábil, 13(52), 26-35. Retrieved from http://www.atena.org.br/revista/ojs-2.2.3-06/index.php/ pensarcontabil/article/view/1195/1130

Barbieri, G., \& Santos, A. (1996). Fim da correção monetária de balanços e início da taxa de juros de longo prazo (TJLP) sobre o capital próprio: alguns de seus principais efeitos. Boletim IOB: Temática Contábil e Balanços, 30(16), 152-162.

Campos, O. V., Lamounier, W. M. , \& Bressan, V. G. F. (2012). Retornos das ações e o lucro: avaliação da relevância da informação contábil. Revista Contabilidade e Organizações - USP, 6(16), 21-38. Retrieved from http://www.rco.usp.br/ index.php/rco/article/view/507/256

Comitê de Pronunciamentos Contábeis-43 - R1. (2010). Initial adoption of CPC technical pronouncements 15 to 41. Retrieved from http://static.cpc.mediagroup.com.br/ Documentos/426_CPC43_R1.pdf

Decree-Law n. 1.452, March 30thof 1976 (1976, March 31st). Incentivizes prioritary projects of the national economy and makes other arrangements. Retrieved from http://www. planalto.gov.br/ccivil_03/decreto-lei/1965-1988/Del1452.htm

Decree-Law n. 62, November 21st of 1966 (1966, November 22nd). Alters the legislation on Income Tax and makes other arrangements. Retrieved from http://www.planalto.gov.br/ ccivil_03/decreto-lei/1965-1988/Del0062.htm

Feitosa, A. (2002). Uma análise dos efeitos inflacionários sobre demonstrações contábeis de empresas brasileiras traduzidas para apresentação no exterior (Master's dissertation). University of São Paulo, São Paulo. Retrieved from http:// www.teses.usp.br/teses/disponiveis/12/12136/tde-20052003152841/pt-br.php

Fisher, I. (1930). The theory of interest: as determined by impatience to spend income and opportunity to invest it. New York, NY: Macmillan.

Franco, G., Kothari, S. P., \& Verdi, R. S. (2011). The benefits of financial statement comparability. Journal of Accounting Research, 49(4), 895-931.

Gabriel, F., Assaf, A., Neto, \& Corrar, L. J. (2005). O impacto do fim da correção monetária no retorno sobre o patrimônio líquido dos bancos no Brasil. Revista de Administração USP, 40(1), 44-54. Retrieved from http://www.rausp.usp.br/ download.asp?file $=$ V4001044.pdf

Gallon, A. V., Silva, T. P., Toledo, J. R., Filho, \& Hein, N. (2009). Análise do ROA sobre as diferentes formas de apresentação do lucro nas empresas do nível 1 de governança corporativa da BOVESPA. Revista de Administração e Contabilidade da Unisinos, 6(1), 49-58. Retrieved from http://revistas.unisinos. br/index.php/base/article/view/4816/2078

Gil, A. C. (2010). Como elaborar projetos de pesquisa (5th ed.). São Paulo, SP: Atlas.

Hendriksen, E. S., \& van Breda, M. F. (1999). Teoria da contabilidade (A. Z. Sanvicente, trad.). São Paulo, SP: Atlas.

Instituto Brasileiro de Geografia e Estatística. (2017a). Indicadores IBGE: sistema nacional de índices de preços ao consumidor - IPCA e INPC. Retrieved from ftp://ftp.ibge.gov.br/ Precos_Indices_de_Precos_ao_Consumidor/IPCA/Fasciculo_ Indicadores_IBGE/ipca-inpc_201703caderno.pdf

Instituto Brasileiro de Geografia e Estatística. (2017b). IPCA: resultados mensais por grupo - 1979 a 1999 - Brasil e áreas. Retrieved from ftp://ftp.ibge.gov.br/Precos_Indices_ de_Precos_ao_Consumidor/IPCA/Resultados_IPCA_e_ INPC_1979_a_1999/IPCA-RELATORIO_1979_a_1999.zip

Instrução CVM n. 248, of March 29th of 1996 (1996). Discusses the elaboration and disclosure of financial statements and quarterly information adapted to the arrangements contained in articles 4 and 5 of Act n. 9,249 of December 26th of 1995. 
Retrieved from http://www.cvm.gov.br/export/sites/cvm/ legislacao/instrucoes/anexos/200/inst248.pdf

Instrução CVM n. 64, of May 19th of 1987 (1987). Discusses the procedures for elaborating and publishing complementary accounting statements, in constant purchasing power currency, in order to fulfill the Monetary Unit Principle. Retrieved from http://www.cvm.gov.br/export/sites/cvm/ legislacao/inst/anexos/001/inst064.pdf

International Accounting Standard 29. (2009). Financial reporting in hyperinflationary economies. Retrieved from http:// ec.europa.eu/internal_market/accounting/docs/consolidated/ ias29_en.pdf

International Monetary Fund. (2017). Consumer price index, all items, percentage change over corresponding period previous years. Retrieved from http://www.principalglobalindicators. org

Iudícibus, S. (2010). Teoria da contabilidade (10th ed.). São Paulo, SP: Atlas.

Kang, T. (2012). The cross-country comparability of IFRS earnings and book values: evidence from France and Germany. Journal of International Accounting Research, 11(1), 185-190.

Klann, R. C., Souza, J. C., \& Beuren, I. M. (2007). O impacto do não reconhecimento da inflação nas demonstrações contábeis e na distribuição de dividendos. Revista de Educação e Pesquisa em Contabilidade, 1(1), 59-78. Retrieved from http:// www.repec.org.br/index.php/repec/article/view/5/5

Krugman, P., \& Wells, R. (2007). Introdução à economia (H. Hoffmann, trad.). Rio de Janeiro, RJ: Elsevier.

Law n. 3.470, of November 28th of 1958 (1959, May 6th). Alters the legislation on Income Tax and makes other arrangements. Rio de Janeiro, RJ: Casa Civil. Retrieved from http://www. planalto.gov.br/CCIVIL_03/leis/L3470.htm

Law n. 4.357, of July 16th of 1964 (1964, July 17th). Authorizes the issuance of National Treasury Bonds, alters the legislation on income tax, and makes other arrangements. Brasília, DF: Casa Civil. Retrieved from http://www.planalto.gov.br/ CCivil_03/leis/L4357.htm

Law n. 6.404, of December 15th of 1976 (1976, December 17th). Discusses joint-stock companies. Brasília, DF: Casa Civil. Retrieved from http://www.planalto.gov.br/CCIVIL_03/leis/ L6404consol.htm

Law n. 9.249, of December 26th of 1995 (1995, December 27th). Alters the legistlation on company income tax as well as the social contribution on net income, and makes other arrangements. Brasília, DF: Casa Civil. Retrieved from http:// www.planalto.gov.br/CCivil_03/leis/L9249.htm

Malacrida, M. J. C. (2009). A relevância do lucro líquido versus fluxo de caixa operacional para o mercado de ações brasileiro (Doctoral thesis). University of São Paulo, São Paulo. Retrieved from http://www.teses.usp.br/teses/ disponiveis/12/12136/tde-27032009-121238/pt-br.php

Martins, E. (1979). Aspectos do lucro e da alavancagem financeira no Brasil (Professorship thesis). University of São Paulo, São Paulo.

Martins, E. (2004). Origem do modelo brasileiro de correção monetária das demonstrações financeiras. Boletim IOB: Temática Contábil e Balanços, 38(45), 1-7.
Martins, E., Gelbcke, E. R., Santos, A., \& Iudícibus, S. (2013). Manual de contabilidade societária (2nd ed.). São Paulo, SP: Atlas.

Melo, S., Martins, E., Nagai, C., Amaral, J. V., \& Salotti, B. M. (2012). Demonstrações contábeis sem efeitos inflacionários: uma abordagem relativa às empresas distribuidoras de energia elétrica. Contabilidade, Gestão e Governança, 15(12), 63-77. Retrieved from http://www.cgg-amg.unb.br/index.php/ contabil/article/view/402/pdf

Parecer de Orientação CVM n. 29, April 11th of 1996 (1996). Divulgação de Informações e Demonstrações Financeiras Voluntárias em Moeda de Capacidade Aquisitiva Constante. Retrieved from http://www.cvm.gov.br/export/sites/cvm/ legislacao/pareceres-orientacao/anexos/pare029.pdf

Perez, J. H., Jr., \& Begalli, G. A. (2015). Elaboração e análise das demonstrações financeiras (5th ed.). São Paulo, SP: Atlas.

Phillips, A. W. H. (1958). The relation between unemployment and the rate of change of money wage rates in the United Kingdom. Economica New Series, 25(100), 283-299.

Porto, P. C. C. (1998). Alguns efeitos da falta do reconhecimento da inflação nos demonstrativos contábeis e seus impactos financeiros: um caso prático (Master's dissertation). University of São Paulo, São Paulo.

Pronunciamento Conceitual Básico - R1. (2011). Estrutura conceitual para elaboração e divulgação de relatório contábilfinanceiro. Comitê de Pronunciamentos Contábeis (CPC). Retrieved from http://static.cpc.mediagroup.com.br/ Documentos/455_CPC00\%20Pronunciamento.pdf

Reina, D. R. M., Reina, D., \& Silva, S. F. (2014). Comparabilidade da informação contábil em empresas brasileiras após a adoção das normas internacionais de contabilidade. Revista Contemporânea de Contabilidade, 11(23), 77-94. Retrieved from https://periodicos.ufsc.br/index.php/contabilidade/ article/view/2175-8069.2014v11n23p77/27702

Resolução CFC n. 1.282/10, May 28th of 2010. Updates and consolidates the arrangements of CFC Resolution n. 750/93, which discusses the Fundamental Principles of Accounting. Retrieved from http://www.cfc.org.br/sisweb/SRE/docs/ RES_1282.doc

Resolução CFC n. 900/01, March 22nd of 2001. Discusses the application of the Monetary Correction Principle. Retrieved from http://www.cfc.org.br/sisweb/sre/docs/RES_900.doc

Salotti, B. M., Lima, G. A. S. F., Corrar, L. J., Yamamoto, M. M., \& Malacrida, M. J. C. (2006). Um estudo empírico sobre o fim da correção monetária integral e seu impacto na análise das demonstrações contábeis: uma análise setorial. Contabilidade, Gestão e Governança, 9(2), 189-221. Retrieved from http:// www.cgg-amg.unb.br/index.php/contabil/article/view/153/ pdf_98

Santos, A. (1980). Aspectos da conversão de demonstrações financeiras para moeda estrangeira (Master's dissertation). University of São Paulo, São Paulo.

Santos, A. (2002). Pior que decepção! Dá para entender os resultados publicados pelas empresas?Boletim IOB: Temática Contábil e Balanços, 36(19), 1-7. 
Santos, A., \& Ribeiro, S. L. S. (2014). Correção monetária: por uma periodização do uso da ferramenta, de 1944 a 1995. Revista Contabilidade \& Finanças, 25, 334-345.

Retrieved from https://www.revistas.usp.br/rcf/article/ view/98021/96828. Special edition.

Stroeher, A. M., \& Freitas, H. (2008). O uso das informações contábeis na tomada de decisão em pequenas empresas. Revista de Administração Eletrônica - USP, 1(1), 1-25.
Retrieved from http://www.rausp.usp.br/Revista_eletronica/ v1n1/artigos/vln1a7.pdf

World Steel Association. (2017). Monthly crude steel production 2016. Retrieved from https://www.worldsteel. org/en/dam/jcr:f982163c-b317-4b26-b998-22abc6e0bdc9/ Crude+steel+production+Dec+2016.pdf

Yip, R. W. Y., \& Young, R. (2012). Does mandatory IFRS adoption improve information comparability? The Accounting Review, 87(5), 1767-1789. 